decentralisation of the British educational system.

Some of the ironies of the British educational system are however neatly described by the report, which is based on an unsystematic survey of the opinions of educational and other organisations and on the CPRS's own views. One large company is quoted as holding the view that university science courses are "too academic" but nevertheless choosing to recruit graduates from the same academic courses in the belief that these would have attracted the most able students.

In its assessment of the provision of education and training, the CPRS echoes the conventional wisdom that Britain is better supplied with means of initial education and training than with facilities for continuing education and retraining.

The report has few concrete suggestions for the improvement of continuing education in Britain. It remarks that elsewhere than in the United Kingdom, and especially in the United States, continuing education flourishes because people acquiring extra qualifications are often rewarded with extra pay, and notes regretfully that "pay policy and union pressure" have prevented such incentives emerging in the United Kingdom. It therefore pins its hope for the future on part-time and evening study.

The more controversial recommendations are, predictably, those that affect the pattern of school education in the United Kingdom. The CPRS comes to the same conclusion as the Secretary of State for Education and Science, Mr Mark Carlisle, that there should be a core curriculum in the age range $11-16$ but that this should be adopted voluntarily by educational authorities and not centrally imposed by Act of Parliament. (The report notes that the only present legal compulsion, the requirement that religious knowledge should be taught in schools, "has not been notably successful".)

The CPRS also wants there to be a more deliberate concern by those who design school curricula for the needs of industry (and is explicitly critical of the School Mathematics Project, now widely used in British schools, for its failure to consult with industry).

On the shortage of science and mathematics teachers in British schools, the report asks that the government should "grasp the nettle" of paying teachers with special skills more than teachers of other subjects. The report does not refer to the longstanding opposition of the teachers' unions to proposals of this kind.

The CPRS also has views about the way in which academics in British higher education should be paid. It refers in its report to the system in the United States under which some academics are paid for only nine months in each year, but are free to take paid employment elsewhere (or to carry out research) in the remaining months.

The CPRS is especially attracted by the way in which this practice may give some academics first-hand experience of industry, and asks that the Department of Education and the University Grants Committee should consider the problem and "use their influence" to get rid of existing restrictions. It hazards no guess at the salary levels that would be established after such a reorganisation.

\section{Three Mile Island}

\section{Reactor entry bid aborted}

AN attempt by two Metropolitan Edison engineers to enter the contaminated containment dome of the damaged Three Mile Island reactor was abandoned last Tuesday (20 May) soon after $9.00 \mathrm{am}$ when the inner door of an airlock refused to open. The engineers made three attempts to open the $3^{\prime \prime}$ thick steel door leading into the containment dome by the normal procedure of giving the wheel of the door a three quarter turn and pushing. After a total of 11 minutes of the planned 15 minute "mission", the men were recalled by radio. A total of 10 millicuries of krypton- 85 was vented to the atmosphere during the procedure and the engineers received a whole body radiation dose of 10 to $15 \mathrm{mrem}$.

Officials from Metropolitan Edison in Middletown, Pennsyivania, and General Public Utilities in Parsippany, New Jersey, said that further attempts to enter the dome would be postponed "indefinitely", until the situation could be analysed further. "We have only one theory" said Sandy Solon of Metropolitan Edison. "Corrosion, either around the hinges or around the door seals, is causing the door to stick". The airlock door is made to close tolerance and has not been opened for 14 months.

By noting which instruments inside the dome have not been operating, engineers have estimated that the dome is flooded to a depth of seven feet, "plus or minus one or two per cent". The airlock door is 20 feet above the floor so "there is no danger of a release of radioactive water into the airlock." Video monitors show a steady mist is falling inside the dome as heat from the reactor (which is still at $200^{\circ} \mathrm{F}$ ) causes water on the dome floor to evaporate, rise to the ceiling and condense. "The atmosphere inside is highly corrosive, to say the least" said Bill Murray of GPU.

The presence of corrosion in the door "bodes ill" for the functioning of ventilation equipment inside required to cool the dome and maintain a negative pressure with respect to the outside to minimise the possibility of leaks. Engineers have rejected the possibility of forcing the door with hydraulic jacks for fear of tearing the polyplastic inflatable door seals. A failure of the air-lock door to reseal might necessitate the uncontrolled venting of the 57,000 curies of krypton-85 still trapped in the dome. Bill Murray of GPU said that the Nuclear Regulatory Commission may give the plant operators permission to make a controlled release of the radioactive gas to the atmosphere, thus

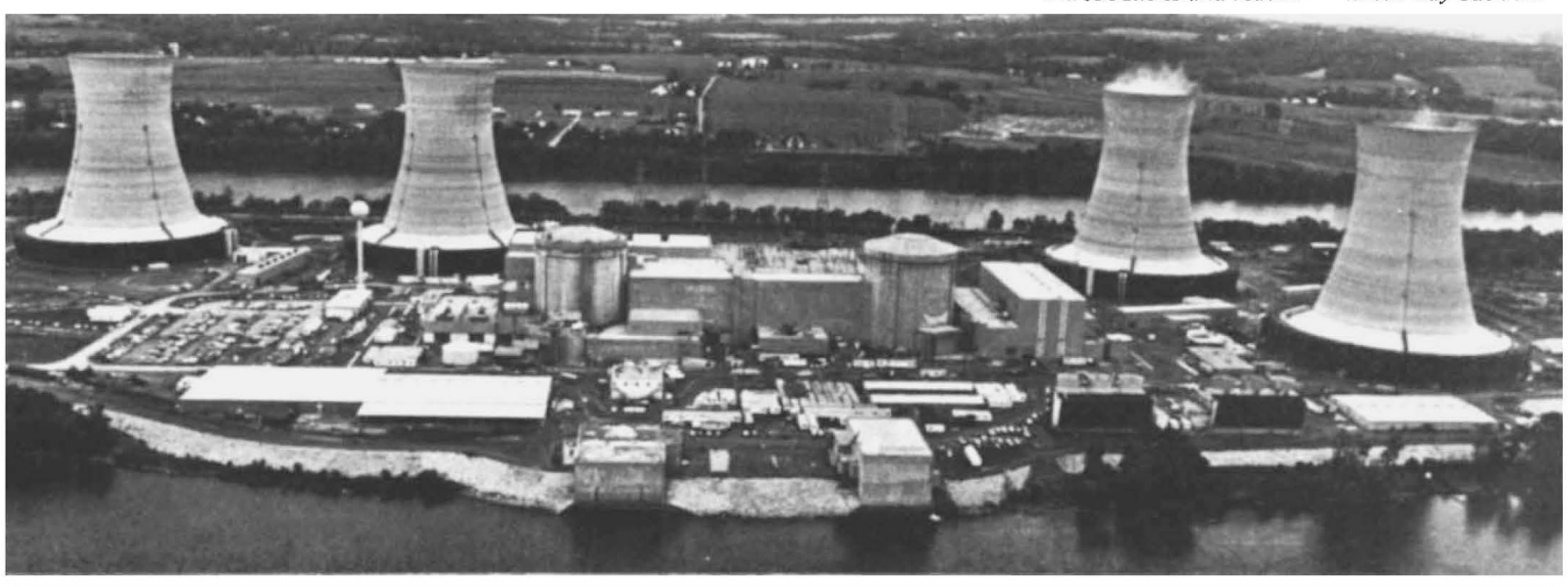


permitting a forced entry. "Hundreds of thousands of curies have already been released with no ill effect. We hope the NRC will let us vent with maximum controlled dispersion and we can then reassess the situation."' Non-gaseous isotopes such as $\mathrm{Sr}-90$ and $\mathrm{Cs}-137$ are presumed to be precipitated on the walls of the dome or trapped chemically in the ventilation filtering system.

The purpose of the attempted 15-minute entry was to monitor radiation in the dome, estimated to be $3 \mathrm{rem}$ per hour of gamma radiation and 200-300 rem per hour of beta radiation. The engineers were also to check for radiation hot spots, examine the ventilation and cooling systems, check for structural damage and take "swipe samples" with gauze of radioactive residues on the walls and stairwells for detailed isotopic analysis.

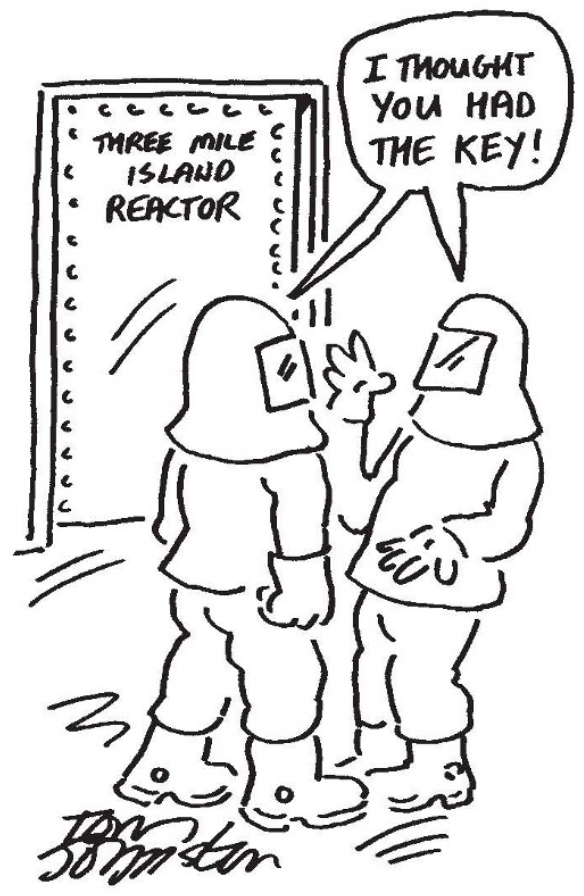

The two engineers, Michael Benson, aged 27, a nuclear engineer employed at Three Mile Island since 1974, and William H. Berhle, aged 36, a project engineer employed there since 1967, were two of several volunteers. They were fitted with Viking dry diving suits (heavy rubber suits of the type used by helmeted deep sea divers) covered by the standard yellow anticontaminant radiation protective plastic clothing. Breathing apparatus was a Scott airpack of the type used by US firefighters with a 30-minute air supply. The men practised for two months on the identical airlock of the second Three Mile Island reactor.

Tuesday's failure was the second abortive attempt to enter the building. A previously scheduled entry on 24 April had to be cancelled when it was discovered that modifications in the breathing apparatus prepared by the Bio Marine company had not been submitted to the National Institute of Occupational Safety and
Health for approval. At a press conference on 21 May, Benson and Berhle said they were "disappointed" and would volunteer again. The GPU said it would announce its next move "within a week".

Joe Schwartz

\section{Recombinant DNA}

\section{Guidelines for scale-up}

\section{Washington}

Like a man with a new pair of shoes, the US National Institutes of Health are experiencing some discomfort in administering industry's voluntary compliance with the safety guidelines covering recombinant DNA research.

Pressures on the NIH are coming from two directions. On the one hand, increasing competition from European and Japanese industry is leading US companies to complain that lengthy procedures for approving new host/vector systems and large-scale fermentation experiments are becoming a commercial handicap.

On the other, the members of the NIH's Recombinant DNA Advisory Commission are feeling their way uncertainly into the engineering and safety aspects of largescale fermentation techniques of which few possess either detailed knowledge or expertise.

The system of voluntary compliance was proposed last year by NIH Director Dr Donald Fredrickson, largely as a way of avoiding the need for new legislation extending the guidelines to the private sector. Since the system was introduced in January, eleven companies have registered their Institutional Biohazard Committees (IBCS) with the NIH, and seven large-scale experiments have been approved.

Last year the containment guidelines were reduced for most experiments to a level requiring minimal physical safeguards, with the result that few companies now feel them to be excessively restrictive. Indeed some take comfort from the fact that Japan has recently introduced the NIH guidelines in their original, more stringent, form.

There is greater concern, however, about the time taken up by NIH's certification procedures, in particular that required to review new host/vector systems - a responsibility which many $\mathrm{RAC}$ members now consider to be one of the committee's most important functions.

At present, for example, the disabled bacterium strain Escherichia coli $\mathrm{K}-12$ is the only approved host/vector system for experiments at the $P 1$ minimum containment level (aithough the use of Saccharomyces cerevisiae strain of yeast is expected to be recommended for approval at RAC's next meeting).

The result, according to Dr Peter Farley, President of the Berkeley-based Cetus Corporation, is that European companies who can locate their operations in countries with minimal certification requirements already have a major commercial advantage through being able to exploit other host/vector systems, such as Bacillus subtilis.

Time is also being taken up by the need for special approval by the Director of NIH for each experiment carried out using more than 10 litres of culture - a relatively arbitrary limit set in the early days of the guidelines and apparently based on conventional laboratory practices.

Amendments to the guidelines which would accelerate the approval process for commercial developments have now been recommended to NIH by Dr Irving Johnson, Vice-President of Research for Eli Lilly and Company, which has already received permission for several scaled-up experiments in the production of human insulin.

In particular, Dr Johnson is proposing that, once approval has been given for a particular experiment to be carried out above the ten-litre limit, further volume increases using the same biological materials at the same containment levels would require merely to be approved by the local IBC.

More controversial is Dr Johnson's suggestion that, in order to make up for RAC members' lack of experience with large-scale applications, industry representatives should be added to the committee with expertise in areas such as fermentation technology and engineering.

And he is also proposing that a permanent subcommittee be set up to advise the Director of NIH on actions related to large-scale applications, with authority to recommend approval of preliminary plans for large-scale operational facilities.

The various proposals will be discussed by the RAC when it meets next week. Their reception is uncertain.

Committee members are aware that they lack expertise in either worker safety or fermentation engineering. "Many have not been entirely happy with their role" says committee member Dr David Baltimore of the Massachusetts Institute of Technology.

Yet there is disagreement over whether this lack should be made up primarily by expanding the scope of the committee, through increased use of consultants or the addition of new members. Or, alternatively, whether greater involvement should be encouraged from agencies which already have statutory responsibility for such matters, in particular the Department of Labor's Occupational Safety and Health Administration.

Either way, it seems increasingly unlikely that there will be new legislation imposing 